71 KIRSTEN THISTED

Lektor

Institut for Tværkulturelle og Regionale Studier, Københavns Universitet

\title{
"EN GIFT I BLODET"
}

\section{Følelsesøkonomier i de dansk- grønlandske relationer}

Der pågår for tiden en heftig debat vedrørende Grønlands fortid. I den alt overvejende del af forskningen indskrives Grønland som en del af den danske kolonihistorie. Året 2017, 100 året for salget af Dansk Vestindien, har længe stået som et pejlemærke for forsknings- og formidlingsprojekter omkring den koloniale fortid, og som hovedredaktørerne skriver i forordet til et af disse initiativer, fembindsværket Danmark og kolonierne, er den hyppigt gentagne påstand om, at Danmark har glemt sin koloniale fortid, snart en sandhed med modifikationer (Brimnes et al. 5). Enkelte historikere har imidlertid stærke forbehold imod at indskrive Grønland i "den store skæbnetunge fortælling om europæisk kolonialisme og imperialisme med alt, hvad dertil hører af racisme, sexisme, tortur, umyndiggørelse og andre overgreb" (Kjærgaard). Ifølge Thorkild Kjærgaard var Grønland ikke nogen koloni, men derimod en slags biland, ligesom Island og Færøerne, og dermed en ligestillet del af riget, hvor grønlænderne absolut ikke var slaver, men slet og ret landsmænd. Tilsvarende synspunkter er fremsat af historikeren Bo Lidegaard, der ligesom Kjærgaard finder, at Grønland på ingen måde tåler sammenligning med Dansk Vestindien "eller med europæiske kolonier i øvrigt". 
Hvorvidt noget er en koloni eller ej, afhænger af, hvordan man definerer begrebet. Som det skal søges demonstreret, er det at vælge at kalde sig en tidligere koloni, eller ikke at gøre det, også en strategisk position. Ordet koloni har været det almindeligt brugte i Danmark, ikke mindst under kolonitiden (1721-1953) og i forbindelse med dennes ophør. Men det er sandt, som Kjærgaard påpeger, at skiftende tider har lagt forskellige betydninger i ordet. At der var tale om en stærkt asymmetrisk relation, har ingen af parterne dog nogen sinde været i tvivl om. Danskerne havde magten og pengene, samt ikke mindst retten til at bestemme, hvad der var rigtigt og normalt, og hvad der var forkert, unormalt, pinligt og ulækkert. Og de gjorde brug af den ret på en daglig basis. Danskere og grønlændere har i århundreder stået i intim forbindelse med hinanden. Som oftest som henholdsvis over- og underordnede, men langtfra altid. Arbejds-, venskabs- og partnerskabsrelationer er indgået, så det ofte kan være vanskeligt at skelne mellem dansk og grønlandsk. Ikke desto mindre er der en grænse, som af begge parter bevogtes nidkært. På et splitsekund kan det enkelte individ gå fra bare at være sig selv til pludselig at inkarnere "danskeren" eller "grønlænderen", med hele den bagage disse figurer slæber rundt på.

Der er rigtig mange følelser investeret her. Følelser som ikke kun er tilfældige og diffuse, men som cirkulerer efter historisk bestemte mønstre, som kobler sig på de magtmæssige og finansielle relationer mellem Danmark og Grønland. Med inspiration fra Sara Ahmeds teori om affective economies vil disse relationer i det følgende blive beskrevet som følelses$ø$ konomier. Mens de finansielle relationer er gennemanalyserede, fordi tal og data er relativt lette at få adgang til, er det langt sværere at få adgang til materiale, som belyser de følelsesmæssige relationer. I denne artikel fokuseres på en e-mail korrespondance mellem to kvinder, som hver især har en fremtrædende plads i den dansk-grønlandske kulturdebat. Analysen vil demonstrere, hvordan disse længst etablerede følelsesøkonomier fortsat dominerer relationerne mellem danskere og grønlændere. Det er artiklens argument, at man ikke forstår de nuværende diskussioner, herunder debatterne om storskalaprojekter, uran og selvstændighed, med mindre man tager højde for disse følelser og deres historicitet. En samtale om forsoning må ligeledes starte her. 


\section{LIDEGAARD OG KLEIST}

I 2016 udgav journalisten og forfatteren Else Lidegaard (født 1933 i Røsnæs ved Kalundborg i Danmark) bogen Med nordlys i øjnene-Genskin fra et liv med Grønland som ballast. Genremæssigt er der tale om en kombination af breve, erindringer, rejsebeskrivelse og interviews. Egentlig havde Lidegaard tænkt sig at udgive sin samling af breve fra årene, hvor hun som ung og nygift - og uuddannet - prøvede at skabe sig et liv i Grønland, som rakte ud over rollen som palasitaap nulia, den nye præsts kone. Ægteparret Lidegaard kom til Grønland i 1953, det år, hvor Grønlands status som koloni ophørte, og Grønland blev en såkaldt ligeberettiget del af Danmark, som det nordligste amt. Det var en spændende tid, og det unge par omgikkes med en lang række personer, som allerede var eller siden skulle blive nøglepersoner i det nye Grønland. Ved nærmere eftersyn var brevene dog for private til at kunne udgives i uredigeret form. ${ }^{1}$ Lidegaard nænnede ikke at skrotte materialet og valgte at omskrive det til erindringsform, men samtidig fandt hun, at det burde suppleres med nutidige stemmer. Derfor er bogen i tre dele, de første to om årene i Grønland 1953-1955 og 1957-1961, den tredje baseret på oplevelser og interviews indsamlet under nylige besøg i Grønland. Alle døre har her stået åbne for Lidegaard, for de ældre husker hende helt tilbage fra dengang, hun var ung, og alle respekterer hende for de mange artikler, radioudsendelser og tv-dokumentarer om Grønland, hun har produceret $\mathrm{i}$ årenes løb. Disse dokumentarer er væsentlige kilder, hvorfra de unge grønlændere i nutiden henter historiske klip til deres egne produktioner. Bogen bliver således både et personligt dokument om en moderne dansk kvindes liv og en fortælling om det moderne Grønland, som Lidegaard har fulgt tæt gennem alle årene.

En af de personer, Else Lidegaard taler med i Grønland, er Makka Kleist (født 1951 i Qullissat i Nordgrønland). Interviewet finder sted i Nuuk i marts 2015, hvor Kleist stadig er leder af den grønlandske skuespiluddannelse. Kleist blev uddannet som skuespiller ved Tuukkaq Teatret i Fjaltring i Nordjylland, etableret i 1975 som en udløber af Odinteatret, hvis ramme var global og universel, bygget på ideen om, at mennesker kan nå hinanden på tværs af forskellige sprog og kulturspecifik æstetik. På Tuukkaq blev den 
ideologiske ramme ideen om de oprindelige folk som et korrektiv til den moderne verden. De oprindelige folks politiske krav var netop da under udvikling, ligesom romantikkens forestilling om en oprindelig harmoni mellem menneske og natur fik en opblomstring og gjorde disse folk og deres stedbundne erfaringsformer til symbol på en tabt før-moderne tilværelse. I Grønland blev de oprindelige folks kamp tænkt sammen med kampen for politisk selvstændighed. Hvor elitens strategi for at opnå ligestilling og anerkendelse før 1953 havde baseret sig på en diskurs om lighed, blev den nu baseret på en diskurs om forskel, som begrundelse for hjemmestyret og ønsket om at opbygge en selvstændig nation.

Efter indførelsen af Hjemmestyret i 1979 rykkede de institutioner, der havde med Grønland at gøre, efterhånden fra Danmark til Grønland. I 1984 flyttede en aflægger af Tuukkaq teatret til Nuuk, under navnet Silamiut. Makka Kleist flyttede imidlertid først til Canada og siden til Norge, hvor hun involveredes i den samiske teaterbevægelse, som ligesom Tuukkaq havde kulturel revitalisering som sit overordnede mål. Gennem mange år har Kleist dannet par med den norske skuespiller Sven Syrin, og de flyttede til Grønland i 2004, da Syrin blev ny leder for Silamiut. I 2009 implementeredes det grønlandske Selvstyre, en videreudvikling af hjemmestyret. Hvor Hjemmestyreloven stadig var formuleret i termer, som fastholdt grønlændere som en etnisk minoritet i det danske rige, anerkendes grønlænderne i Selvstyreloven som et selvstændigt folk med retten til at etablere sin egen nationalstat. Som et led i en sådan nationsbygning vedtog Grønlands Selvstyre i 2010 en grønlandsk teaterlov. I 2011 skiftede Silamiut navn til Nunatta Isiginnaartitsisarfia / The National Theater of Greenland. Kleist var leder af den grønlandske skuespiluddannelse fra dennes start i 2007 til 2016.

De to kvinder har således ikke kun forskellig etnicitet, de tilhører også hver sin generation. Hvor Lidegaard var ung med visionen om Grønland som en integreret del af Danmark, var Kleist ung med visionen om et selvstændigt Grønland. Dette afspejler sig naturligvis i deres kommunikation, men det er undertegnedes erfaring, ikke mindst fra den kommunikation, som udspiller sig i mediedebatter og på de sociale medier, at tilsvarende konfrontationer også finder sted blandt yngre mennesker. 


\section{MELLEMREGNINGER}

Da de to kvinder mødes i 2015, ved de allerede en masse om hinandens arbejde, og de kender også hinanden lidt på forhånd. De er begge interesserede i, at kommunikationen skal lykkes. Kleist sørger endda for, at Lidegaard inden interviewet får set den forestilling, som for øjeblikket er sat op på teatret: The Nomadic Woman, opført af det polske Amareya Theatre. Forestillingen er skabt af den polske instruktør og performer Katarzyna Pastuszak, i samarbejde med den grønlandske fotograf og journalist Louise Fontain. ${ }^{2}$ Forestillingen bygger på Fontains personlige beretning om den følelse af fremmedgørelse og identitetstab, som grønlandske børn oplevede, når de sendtes til Danmark på ét års skoleophold. I perioden 1961 til 1976 kom omkring 1.600 grønlandske børn til Danmark på den måde. Det skete med fuld tilslutning fra de grønlandske familier og bør ikke forveksles med det totalt forfejlede projekt, som ligger bag spillefilmen Eksperimentet fra 2010 om 16 grønlandske børn, som i 1951 blev fjernet fra deres familier og aldrig sendt tilbage igen. Ikke desto mindre oplever Fontain en sammenhæng, oplyser Lidegaard, som taler med hende i pausen (Lidegaard 232). Fontain medvirker selv i stykket, hvor hun beretter brudstykker af sin historie. På teatrets hjemmeside oplyses, at stykket er inspireret af Rosi Braidottis begreb "nomadic subjects", der fokuserer på den værdi, som også kan ligge i ikke at være fast forankret i på forhånd givne sociale sammenhænge. Stykket beskrives her som "en metaforisk genfødelse og kvindens tilbagevenden til sig selv og verden" (Amareya Theatre, min oversættelse). Lidegaard oplever helt klart ikke stykket på den måde, men ser det snarere som en "tilbagevenden til offerrollen". Dette er naturligvis et tema, hun tager op i interviewet med Kleist.

Som det er almindelig praksis, sender Lidegaard bagefter den redigerede tekst om sit besøg på teateret og sin samtale med Kleist til godkendelse. Kleist gør indsigelser og indfører rettelser, og det interessante er, at Lidegaard vælger at trykke både sin originale tekst, Kleists rettelser, samt sine egne kommentarer til Kleists rettelser. Hun siger selv, at det med det samme stod hende klart, at det især er disse "mellemregninger" i teksten, der har almen interesse. Hun gengiver korrespondancen med tilladelse fra Kleist.

Forestillingen havde premiere i 2012. Den kan ses på YouTube. 
Indledningsvis udtrykker Lidegaard sin forbavselse over, at hendes oprindelige tekst har kunnet provokere Kleist, eftersom der for det meste kun er tale om "ord som for mig var ganske uskyldige og neutrale" (237). Disse ord kunne imidlertid i Kleists optik "indeholde en postkolonial overlegenhed", og Lidegaard rammesætter således fra starten eksemplet som visende "en sårbarhed hos hende og en manglende lydhørhed hos mig, som det ellers kan være vanskeligt at påvise" (237). Dette udsagn vil i det følgende selv blive gjort til genstand for analyse. Hensigten er på ingen måde at kritisere eller udstille Lidegaard, eller for den sags skyld Kleist, men alene at tænke videre ad det spor, de to så generøst har lagt ud. Lidegaard har efter min mening set helt rigtigt, når hun fornemmede, at hun her har fat i noget, som har en almen værdi, og som vil kunne genkendes af mange. I de følgende uddrag står Lidegaards oprindelige tekst med umarkeret skrift, Kleists kommentarer med fed, og Lidegaards kommentar til Kleists kommentar med kursiv, sådan som det er gengivet i Lidegaards bog.

\section{SUBJEKTPOSITIONER}

Hej Else. Nu har jeg læst og læst igennem det du har skrevet. Jeg har rettet meget på det, og den du skrev om Louises "Nomadic Woman" er helt misforstået, så jeg sendte den til Louise selv.

Inussiarnersumik inuulluaqqusillunga /Warm regards

Makka Kleist

Nunatta isiginnaartitsinermik Ilinniarfiata pisortaa

Artistic Director / Principal of the National Theatre of Greenland (237).

Kleist signalerer med disse ord, at hun er grundlæggende uenig i Lidegaards fremstilling, men også at hun har investeret tid og energi på at arbejde med den, bortset fra det som handler om teaterstykket, som hun har sendt videre til Fontain. Kleist har kommentarer til Lidegaards tekst lige fra starten, hvor teatret præsenteres:

...og i 2011 er den [Silamiut] så blevet afløst af hvad der på flot dansk hedder Grønlands Nationalteater - (hvorfor "flot" dansk? - det hedder den faktisk - det lyder som om at Grønland ikke kan have et nationalteater?)

(Svar) Fordi det er flot at der i en befolkning på 55.000 mennesker er kreativitet og vilje nok til at lave et nationalt teater. Og da det ikke står på dansk udenfor-som jeg citerede 
på de to sprog der anvendes [teatret bruger grønlandsk og engelsk, ikke dansk] -og da min bog jo bliver til et dansktalende publikum - vendingen (237).

Kleist finder formuleringen "på flot dansk" stødende, fordi den indikerer en diskrepans mellem navnet og indholdet - som om navnet er for ambitiøst i forhold til det, som faktisk foregår på det pågældende teater. Lidegaard ville næppe have brugt en tilsvarende formulering om eksempelvis Det kongelige Teater, hvis intentionen alene var at oversætte teatrets navn fra grønlandsk og engelsk til dansk. Med det lille adjektiv "flot" i vendingen "på flot dansk" aktiverer Lidegaard de gamle majoritets-minoritetsrelationer, som gav danskeren retten til at definere og vurdere grønlænderen. Dansk bliver den norm, hvorudfra grønlandsk, i dette tilfælde det grønlandske nationalteater, defineres som det afvigende anderledes: en position, som er behæftet med skam, fordi man objektgøres for den andens og ens eget blik.

Objektgørelse for den andens blik beskrives i filosofien som universel for det menneskelige subjekt. I sin spændende udredning af begrebet skam tager filosoffen Dan Zahavi blandt andet udgangspunkt i Jean-Paul Sartre, som ser skammen som en følelse, der frem for nogen anden åbenbarer vores eksistens som afhængig af relationer, "our being-for-other"; at man er til i kraft af, at man er til for andre mennesker (Zahavi 213). Skam behøver derfor ikke at handle om noget moralsk forkasteligt, man har gjort. Det er selve det at erfare, at man ikke kun er det almægtige subjekt, man ser sig selv som, men at man for den andens blik figurerer som et objekt på linje med andre objekter, der udløser skam, forklarer Sartre. Man opdager sin egen magtesløshed i forhold til denne objektgørelse og tvinges til at se sig selv med den andens blik, med alle ens fejl og mangler.

I ethvert barns opvækst forekommer der altså dette afgørende punkt, hvor man tvinges ud af forestillingen om sig selv som det omdrejningspunkt, hvorfra hele verden anskues. Magtrelationer afgør imidlertid, i hvor høj grad man individuelt og som gruppe kan komme igennem med at opstille sig selv som normen og tvinge andre til at se sig selv gennem ens eget blik. I bogen The Anti-Semite and the Jew taler Sartre om, hvordan objektgørelsen hos den stereotypiserede, ringeagtede minoritet kan ende med at blive "overdetermineret indefra", idet stereotypen bliver det skrækbillede, som minoriteten bestandig må grue for at komme til at leve 
op til, mens idealbilledet er optaget af majoriteten (68). Den antikoloniale psykiater og filosof Frantz Fanon sammenligner dette med den sortes situation. Der er et overlap, men der er også forskel, mener han. Jøden kan forblive uopdaget i sin jødiskhed, det vil sige passere som hvid, eftersom han basalt set er en hvid mand, tilhørende en race, som aldrig har gjort sig skyldig i kannibalisme (115). Jøden er således et menneske, for han ved, at han ikke er ét med stereotypen af ham, og derfor er han stadig subjekt i sit eget liv, uanset hvor meget andre gør ham til et objekt.

Anderledes forholder det sig med den sorte. I begyndelsen af Black Skin White Masks fremsætter Fanon dette provokerende statement: "Med fare for at vække mine farvede brødres vrede, vil jeg sige, at den sorte mand ikke er noget menneske" (10, min oversættelse). Den sorte er nemlig ikke sit eget subjekt. Han har lært og internaliseret, at det menneskelige subjekt er hvidt, og derfor er det, som den sorte mand virkelig ønsker sig her på jorden at blive hvid. For den sorte drejer det sig om at komme til erkendelse om dette. For før den sorte giver slip på den internaliserede idealisering af den hvide mand, vil han forblive den hvide norms "Anden". Herved forbliver han ét med sin skam og sit mindreværdskompleks.

Relationerne mellem danskere og grønlændere har langt fra lignet relationerne mellem sorte og hvide. Ikke desto mindre har race - og racisme - været et væsentligt element i det dansk-grønlandske set-up, og diskussionen om præsentationen af det grønlandske nationalteater handler om denne helt centrale problematik: retten til at være sit eget subjekt. Bestandig er den grønlandske elite, og siden også resten af befolkningen, blevet opfordret til at måle sig selv ud fra et dansk idealbillede, som de aldrig ville kunne nå, men dog bestandig måtte stræbe imod. Alt det arbejder grønlænderne på at deaktivere, men bliver fra dansk side igen og igen mødt med en fastholdelse af de gamle normer. Som når Lidegaard med sin formulering om det grønlandske nationalteater uvilkårlig måler dette i forhold til den danske (ideal)model. Måske har hun ikke ment det sådan, men det er sådan, det bliver læst af Kleist.

Lidegaard kommer hele tiden til at tale ind i dette rum, som Kleist lige så vedholdende forsøger at tale sig ud af. Efter udvekslingen omkring teatrets navn, følger denne passage: 
... Inspiration og viden fra stammefrænderne er vigtigere end fra Danmark (Hvorfor skal Danmark nævnes?). Men selvfølgelig skal de også lære de store dramatikere at kende.

(Svar) Fordi Danmark hidtil har været så dominerende en faktor. Det er jo her I skiller jer ud-på den gode måde (217-18).

Med sin insisteren på at fastholde Danmark som referencepunkt modarbejder Lidegaard den demontering af den faste relation Danmark-Grønland, som teatret har søgt at opnå ved at skifte dansk ud med engelsk. Kleist har to elementer i spil: inspirationen fra de andre Inuit og inspirationen fra "de store dramatikere", hvor der helt klart tænkes i en international/global skala. Det ved Lidegaard naturligvis godt, men for hende går inspirationen fra verden til Grønland gennem Danmark, som hun også understreger det i sin kommentar til kommentaren. Referencen til historien er også en reference til Danmarks betydning for Grønland og en insisteren på ikke at skrive denne betydning ud af historien nu. Sætningen "Det er jo her I skiller jer ud - på den gode måde" sigter på at afrunde og mægle, men kommer til at virke patroniserende, netop fordi den yderligere understreger Lidegaards majoritetsposition som den, der har magten til at vurdere og bedømme den anden.

\section{SPROG OG POSTKOLONIALE MAGTFORHOLD}

Som fremgået af diskussionen om teatrets navn, og som det også fremgår af Makka Kleists signatur i mailen citeret ovenfor, har man altså valgt, at grønlandsk og engelsk skal være teatrets to hovedsprog. Teatret følger en almindelig praksis i Grønland i disse år, hvor dansk udskiftes med engelsk. Der sendes hermed et signal om, at grønlænderne agerer i et internationalt/ globalt rum, ligesom man opsiger den gamle binding til Danmark, som udsprang af de mange år med dansk monopol på handel og rejseaktivitet til og fra Grønland. Grønlands regering præsenterer sig tilsvarende som Naalakkersuisut/Government of Greenland på skilte, brevpapir og hjemmesider. En anden ting er, at det i hvert fald indtil for nylig har været så som så med indhold på den engelske version af hjemmesiden. Ofte har man kunnet finde masser af nyheder på både den grønlandske og den danske side, mens man på den engelske er blevet mødt med den lakoniske besked: "There is nothing to show". Det handler naturligvis ikke om, at nyhederne 
er forsvundet i cyberspace, men at ingen har nået at oversætte. Dansk er, af historiske årsager, alment brugt i Grønland og fungerer fortsat i mange sammenhænge som et magtsprog: Mange embedsmænd, journalister, erhvervsledere, læger, lærere, eksperter, konsulenter osv. taler kun dansk, og derfor går oversættelsesstrømmen mestendels fra dansk til grønlandsk. At oversætte alting mellem disse to sprog er særdeles ressourcekrævende, og derfor er det svært at finde kræfter til yderligere en oversættelse til engelsk, også fordi kompetencerne mangler. Alle i Grønland kender denne problematik og er pinligt berørte over den. Lidegaard træder således på ømme tæer, når hun bringer emnet op, fordi insinuationen om, at teatrets navn skulle være lige lovlig prætentiøs, også kan associeres med sprogvalget.

Dansk i Grønland er altid en følelsesladet diskussion for både grønlændere og danskere. Mange danskere føler sig stødt, når grønlændere siger, at de gerne vil af med dansk. Grønlændere føler sig til gengæld i deres gode ret til at insistere på grønlandsk som hovedsproget i Grønland, i overensstemmelse med både hjemmestyrelov og selvstyrelov. At afvise dansk er imidlertid også en form for afvisning over for et land og et sprog, som mange grønlændere føler afviser dem. ${ }^{3}$ Alle disse ting er på færde i diskussionen mellem Lidegaard og Kleist. Om sprogspørgsmålet bringer Lidegaard følgende fra e-mail korrespondancen:

Der er kun få af dem [skuespillerne uddannet ved uddannelsen i Grønland], der arbejder som skuespillere. ("Vi bliver aldrig brugt på de danske teatre", beklager hun). Det sagde jeg ikke. Jeg sagde det i forbindelse med hvorfor vores sprog på teatret er grønlandsk og engelsk. Selv dem der er uddannet i Dk, bliver sjældent brugt på de danske scener, so why bother (238).

Valg af sprog handler således om uendelig meget andet end lige netop sprog. Sprog har gennem tiden frem for noget andet trukket grænsen mellem de etniske grupper i Grønland. ${ }^{4}$ Som man ser, har sproget fortsat denne gensidigt udelukkende funktion.

3 At et ikke ubetydeligt antal grønlændere har dansk som førstesprog, gør absolut ikke sagen lettere. Disse grønlændere føler sig omvendt afvist i Grønland.

4 Lidegaards beretning om sin egen tid i Grønland og de ihærdige, men umulige forsøg på at lære grønlandsk og krydse grænsen er her i sig selv en spændende kilde. 
Konflikten topper, da Kleist trækker kolonialismekortet. Det sker i forbindelse med diskussionen om The Nomadic Woman, hvor Kleist med sin bemærkning om "den megen smerte" anslår den diskurs, som historikeren Thorkild Kjærgaard benævnte "den store skæbnetunge fortælling om europæisk kolonialisme og imperialisme med alt hvad dertil hører af racisme, sexisme, tortur, umyndiggørelse og andre overgreb", jf. indledningen til denne artikel. Denne diskurs dukkede op i Danmark og Grønland i 1960'erne og fungerede som en moddiskurs til fortællingen om det venlige Danmark, der havde taget det på sig at hjælpe Grønland frem til modenhed og selvstændighed. I den dominante diskurs fremstod Danmark som en indfølende kolonimagt, der egentlig slet ikke kunne regnes som en kolonimagt. I moddiskursen blev Danmark nu pludselig beskrevet som en kolonimagt på linje med de andre store og brutale kolonimagter. Hvor den dominerende diskurs gerne visualiseredes i billeder af glade, nationaldragtklædte grønlændere viftende med det danske flag, ledsagedes moddiskursen af billeder af drukne, hjemløse grønlændere, til illustration af den ulykke, som kolonisering, modernisering og tvangsdanisering af grønlænderne havde medført - alt sammen temaer, som var nøje knyttet til fortællingen om Danmark som del af den vestlige imperialisme. Lidegaard afviser prompte denne udgave af den koloniale diskurs:

'Man er nødt til at bearbejde smerten, mener Makka, der er så meget smerte.' Jeg tilstår at jeg ingen smerte føler i forhold til Grønland, heller ikke specielt dårlig samvittighed eller skyldfølelse. (nej, hvorfor skulle du - du repræsenterer jo kolonimagten og er kolonialist, derfor kan du ikke se hvad man har gjort galt.)

Må jeg bruge din replik? Ja! Så vil jeg svare:

Du har ret $i$ at både det at have været koloniseret og at have været koloniherrer er en gift $i$ blodet som det tager mere end en generation at komme over, og som næppe kan undgå at præge ens opfattelse af tingene. Men skal man videre mener jeg at man må bekæmpe både offer-og skyldkomplekserne (238).

Som det fremgår, benægter Else Lidegaard ikke, at der har været tale om en kolonirelation, eller at denne har haft negative konsekvenser, jf. den stærke metafor "en gift i blodet". Men hun afviser, at de offer- og skyldskomplekser, som er indlejret i koloniproblematikken, er andet end netop "komplekser", som det drejer sig om at lægge bag sig. På den måde kan hun afvise at tage problematikken personligt, som noget hun selv har del i, samtidig med at 
hun uden at ryste det mindste på hånden tildeler sig selv det sidste ord i samtlige af disse orddueller med Kleist.

I passagen ovenfor virker det lidt unfair, at Lidegaard tildeler sig selv den slutreplik i dialogen. Makka Kleist er særdeles bevidst om, at ikke kun skyldkomplekser, men også offerkomplekser bør bearbejdes. Det er præcis derfor, hun stiller sig skeptisk over for den grønlandske forsoningskommission. Mere om dette senere. Lidegaards replik kunne i princippet lige så godt have været Kleists egne ord. Under alle omstændigheder ville det have været interessant at få en dybere forklaring på uenigheden, som udspringer af The Nomadic Woman. Her ville vi gerne have hørt Kleists opfattelse af stykket, samt ikke mindst en uddybning af, hvad hun mener med at "bearbejde smerten". Hvordan ser hun teatrets og skuespiluddannelsens rolle i den forbindelse? Sådanne spørgsmål kan man med sikkerhed gå ud fra, at den garvede journalist ville have stillet, hvis den interviewede havde været alt andet end netop grønlænder. Passagen viser, hvordan det i dansk-grønlandske relationer let bliver forforståelserne, der taler, frem for en egentlig uddybning af problematikken. At almindelige regler for sådanne faste, script-prægede situationer, som her forholdet mellem interviewer og interviewet, ofte suspenderes, når rammen er Danmark-Grønland, er i sig selv bemærkelsesværdigt og siger noget om den fastlåsthed, relationen er havnet i.

\section{FØLELSESØKONOMIER}

Det har tydeligvis været Lidegaards hensigt at opnå en ligeværdig dialog. Det er baggrunden for projektet med de nye rejser til det selvstyrede Grønland: at give plads til grønlandske stemmer. Lige fra den første ankomst til Grønland i 1953 er Lidegaards rollefigur i teksten skildret som progressiv, i modsætning til det langt fra progressive danske koloniale styre og de andre danskere, "med deres 'væren bedre' end grønlænderne fra fødslen af. Det er utroligt, hvad de kan få sig selv til at sige..." (Lidegaard 10). Allerede inden hun ankommer til Grønland, har Lidegaard således gjort sig "umulig i de Godthåb bourgoisikredse" (10), fordi hun insisterer på at se danskere og grønlændere som ligeværdige. Lidegaard placerer dermed sig selv uden for eller hævet over den koloniale problematik. Spørgsmålet er, om en sådan positionering er mulig i praksis. Hele det koloniale set-up går ud 
på at indlejre parterne i på forhånd udstukne relationer, og dem kommer ægteparret Lidegaard også til at leve efter i Grønland. For to unge danskere, med og uden uddannelse, er Grønland et mulighedernes land. De får alle de tilbud, de kan overkomme. Ud over det arbejde, Mads Lidegaard er ansat til at udføre, er der ingen ende på tilbud om foredrag og kurser, og for Elses vedkommende radiooplæsninger, skuespil, undervisning, noget af det i fag hun selv erkender kun at bemestre meget dårligt. Og det hele er vel at mærke lønnet arbejde. Meget af det har givet været til stor gavn for Grønland, især den dansktalende elite, for det hele foregår jo på dansk.

Ægteparret Lidegaard lever ikke som grønlændere. De lever, som udsendte danskere før og efter dem, i deres lille boble af danskere, tilsat en række personer fra den grønlandske elite, som ser danskerne som en vigtig alliance i grønlændernes vej ind i det moderne samfund og opad på den sociale rangstige. Alt dette ved vi, fordi Lidegaard selv fortæller om det og reflekterer over det. I bogens to første dele, baseret på brevene hjem fra årene i Grønland, veksler uddrag fra brevene med nutidige betragtninger. Lidegaard har et skarpt blik for, hvordan de to unge fanges i de samme mønstre, de kritiserer hos andre. Uanset om de vil det ej, spiller ægteparret deres roller som del af det danske projekt med Grønland efter 1953. Fra at have været lukket og beskyttet og isoleret, skulle Grønland nu trækkes med ind i den moderne verden, og det skulle gå stærkt. Danskerne kommer væltende, de sprænger og de bygger og de regerer. Det er grønlænderne, der skal bo i husene. Det er bare ikke dem, der bygger dem op. Det er der slet ikke tid til. Lidegaard stiller sig stærkt kritisk overfor alt dette. Men i hvor høj grad har noget tilsvarende gjort sig gældende på det kulturelle område? "Spørgsmålet var om vi virkede anmassende når vi tog initiativer", spørger Lidegaard forsigtigt, nu hvor hun ser på det hele igen 50 år efter (183).

Arbejdet med bogen har tydeligvis udfordret Lidegaards selvfortælling omkring årene i Grønland, og det er dybt interessant at følge, hvordan hun her i sin høje alder forsøger at konfrontere sig med disse nye vinkler, som dukker op. Frem for alt bliver det vigtigt for hende at demonstrere sin taknemmelighed for alt det, hun har modtaget, og således underminere den dominante diskurs om danskerne som giverne, og grønlænderne som modtagerne i relationen, jf. også bogens undertitel. Udvekslingen med Makka Kleist kommer imidlertid til at demonstrere grænsen for, hvor 
langt Lidegaard kan og vil gå i en sådan genforhandling af roller og identitetspositioner. Det kan her være relevant at se nærmere på den tidligere citerede passage om, at korrespondancen skal illustrere en "sårbarhed" hos Kleist og en "manglende lydhørhed" hos Lidegaard selv. Passagen står som en slags læsevejledning i åbningen af afsnittet, inden vi læser uddragene fra korrespondancen, og kommer således til at rammesætte hele afsnittet.

Det, som umiddelbart er interessant ved passagen, er, hvordan den opfylder faste forventninger i den dansk-grønlandske diskurs. Man kan forestille sig, at Lidegaard havde sagt det modsatte: at det afslørede en sårbarhed hos hende selv og en manglende lydhørhed hos Kleist. Eller rettere: Det kan man netop ikke forestille sig. I det dansk-grønlandske set up er rollerne fordelt således, at det primært er grønlænderne der føler, og danskerne der analyserer og ræsonnerer. I en opfølgende mail undskylder Lidegaard således for "alle de følelser du har måttet igennem", ligesom hun beder Kleist om ikke at være vred (238). Men hun siger intet om, hvilke følelser hun selv har måttet igennem. Det tætteste man kommer, er den angst hun helt tydeligt nærer for at blive afvist af den anden - hun håber sådan, at de fortsat kan tale sammen, skriver hun (239).

Den feministiske kulturforsker Sara Ahmed har introduceret begrebet affective economies (The Cultural Politics of Emotion). Ideen om følelsernes cirkulation og akkumulation er lånt fra marxismen: Ganske som penge akkumulerer værdi gennem cirkulation, således cirkulerer følelser og kreerer følelsesmæssig værdi. Følelserne cirkulerer ikke frit, de binder sig til objekter: nogle objekter forbindes med lykke, andre med det modsatte. Den lykkelige familie er for eksempel et oplagt lykkeobjekt, og lykke og glæde binder sig til de kroppe, som gnidningsfrit kan tage denne rolle på sig, mens ulykke og ubehag kommer til at "klistre" til kroppe, som ikke kan eller vil (Ahmed, The Promise of Happiness). På samme måde cirkulerer racistiske diskurser følelser af overskud og mindreværd, som får lykke til at klistre til den hvide krop, mens ulykke og tragedie klistrer til den sorte krop. ${ }^{5}$ I den danske diskurs om de dansk-grønlandske relationer cirkuleres

5 Ahmed taler, med inspiration fra Judith Butler, bevidst om kroppe for at understrege, at vi er i verden med vores kroppe, og at nogle kroppe passer bedre ind i de sociale scenarier, vi opstiller, end andre kroppe. 
godgørenhed og kærlighed. Danskernes kærlighed til grønlænderne har været gentaget som et mantra gennem tiderne, ikke mindst første halvdel af 1900 tallet, hvor det koloniale styre reelt var under pres, dels fra intern dansk kritik, dels fra grønlandsk side, og efter afslutningen af Anden Verdenskrig fra FN (Andersen og Thisted). Jo oftere denne danske kærlighed og godgørenhed gentages i skrifter og taler og hverdagsfortællinger, jo varmere og mere inderlig bliver kærligheden - samt forventningerne om dens gengældelse. Diskursen er baseret på familiemetaforer: Danmark har taget Grønland til sig i et forhold som en moder til sit barn og har dermed påtaget sig ansvaret for dets opdragelse og uddannelse, indtil det punkt, hvor Grønland er voksen og moden nok til at træde ind i de voksnes rækker blandt andre nationer på lige betingelser. Indtil den fase indtræder - og forældre og børn er som bekendt sjældent enige om, hvornår det sker forventes der lydighed, samt naturligvis den gengældte kærlighed, loyalitet og respekt, man skylder sine forældre.

Gennem denne cirkulation af følelser klistrer således overskud, gavmildhed og hjælpsomhed til danske kroppe, mens utilstrækkelighed, taknemmelighed og underdanighed klistrer til grønlandske kroppe. Det er denne økonomi, Kleist reagerer mod med sine indsigelser mod Lidegaards manuskript, idet hun slår ned på de formuleringer, hvor grønlændernes mindreværd eller anden-position i forhold til det danske tages for givet og gencirkuleres. Hermed udfordrer hun imidlertid Lidegaards selvforståelse som en person, der har formået at sætte sig uden for den koloniale diskurs, og som har bidraget til kolonialismens afvikling. Kleist kommer således til at indtræde i rollen som affect alien eller killjoy, de begreber, hvormed Sara Ahmed betegner sådanne personer, som ikke lader sig indforskrive i den almindelige cirkulation af lykke, og som derfor underminerer de andres lykke: Som for eksempel den lesbiske, der forkaster kernefamilien, eller indvandrerfamilien, der forkaster majoritetens værdier. Lidegaard genopretter sit eget narrativ og sit selvbillede ved omvendt at tilskrive Kleist rollen som det oversensible, skrøbelige grønlandske subjekt, som det robuste danske subjekt har en forpligtelse til at lytte til og tage vare på. Hermed reproducerer hun imidlertid præcis dén koloniale diskurs om danskernes følelsesmæssige og kulturelle overlegenhed, som hun hævder altid at have modsat sig. 
Kleist har tilsyneladende ikke haft nogen mulighed for at kommentere den samlede version af udvekslingen, herunder bemærkningen om hendes "sårbarhed" overfor de mindste ting, der kan tolkes som danskerens postkoloniale overlegenhed, de ting som for Lidegaard fremstår som "uskyldige og neutrale" ord og sætninger. Teksten illustrerer, hvordan den koloniale diskurs bliver ved med at tale, netop gennem disse selvfølgeliggjorte talehandlinger, som for danskeren forbliver fuldstændig ubemærkede. ${ }^{6}$ Ved på denne måde at give os mulighed for at få øje på, hvordan det foregår, giver Lidegaard os imidlertid også muligheden for at få det til at høre op.

\section{SKYLD, ANSVAR OG FORSONING}

Situationen, hvor Kleist påtaler smerten og dermed introducerer diskursen om den koloniale skyld, som Lidegaard ikke vil tage på sig, men alligevel ser sig nødsaget til at forsvare sig imod, spejler situationen, da den daværende formand for Naalakkersuisut (den grønlandske regering) Aleqa Hammond (Siumut) ved rigsmødet (det årlige møde mellem Danmark, Grønland og Færøerne) i 2013 lancerede den grønlandske forsoningskommission. Den daværende danske statsminister, Helle Thorning Schmidt, betakkede sig på det efterfølgende pressemøde for enhver deltagelse med ordene: "Vi [danskerne/den danske regering?] har ikke behov for forsoning, men jeg har fuld respekt for, at det er en diskussion, der optager det grønlandske folk. Vi vil følge diskussionen nøje herfra" (KNR nyheder). Ordene vakte en vis undren i Grønland, eftersom der jo normalt er tale om en forsoning mellem parter, og det derfor ikke rigtig giver mening, hvis den ene part ikke vil være med. Ideen om en forsoningskommission blev imidlertid langt fra mødt med entydig opbakning i Grønland. Mange mente, at ordet "forsoningskommission" er associeret med Sydafrika og derfor ikke hører

6 Jf. at "klistreeffekten", som Ahmed taler om, opstår gennem repetition og indlejring af diskurser, stereotyper og affektive praksisser over lange historiske forløb, hos Ahmed benævnt fortidige associationshistorier ("past histories of association"), som ofte lever videre i det skjulte, ikke mindst når emnerne er ømtålelige og tabubelagte (The Cultural Politics of Emotion 13). 
hjemme i forbindelse med Grønland (Thisted 162). Kleist udtrykker præcis den samme holdning:

Hvad skal vi forsones om? Det er et forkert ord, for det får en til at tænke på Sydafrika, og det hører ingen steder hjemme. Kunne man ikke i stedet for kalde det en historiekommission, for det er vigtigt at kende de reelle facts. Og at der er respekt fra begge sider (236).

Det er bemærkelsesværdigt, at netop Makka Kleist stiller sig så forbeholden over for forsoningskommissionen. Både hendes brug af emnet smerte og den måde, hun spiller kolonikortet på, trækker ellers på den diskurs, som lå bag de oprindelige tanker om at indføre emnet forsoning $i$ en grønlandsk sammenhæng. ${ }^{7}$ Også blandt de ældre generationer er der imidlertid for nuværende en opmærksomhed omkring, at det gælder om at tage agens, i betydningen råderet og ansvar over eget liv. Det er tydeligt, at Kleist tolker bearbejdelsen af smerten ind i dette perspektiv, jf. også den tidligere omtalte præsentation på nettet af det stykke, hun og Lidegaard er uenige om. Derfor er det også væsentligt, at grønlænderne selv kom til at sidde for bordenden i det, som netop blev en grønlandsk kommission, og at arbejdet kom til at fokusere på egne handlinger og dermed eget ansvar. En forsoningskommission, hvor vægten havde været på danskernes skyld, ville også have tildelt dem ansvaret, og dermed snarere have fungeret som en bekræftelse af den koloniale diskurs end som en dekonstruktion af denne, eftersom det danske styres legitimitet jo netop hentedes i argumentet om Danmarks ansvar for Grønland. Skam ville dermed fortsat have klæbet til den grønlandske krop, fordi grønlænderne ville være forblevet i objektpositionen, som det passive mål for andres handlinger. Et sådant set-up ville derfor næppe formå at rokke ved den etablerede majoritets-minoritetsrelation Danmark og Grønland imellem.

Faktisk levede forsoningskommissionens kommissorium fra 2014 meget godt op til det forslag om en historiekommission, som Kleist stiller, idet det fokuserede på grønlændernes forsoning med historien og deres egen rolle heri:

7 Tanken om forsoning søsattes i slutningen af 1990-erne af psykiateren Fatuma Ali, der i en årrække arbejdede i Grønland. I 2004 afholdtes det første seminar. Se henvisninger i Thisted. 
Målet for kommissionens arbejde er at skabe dialog og indblik omkring den socio-historiske udvikling i Grønland, således at man som samfund tager ved lære af konsekvenserne omkring egne handlinger for derigennem at skabe bedre rammer for fremtiden (Naalakkersuisut 1).

Det er således ikke kun det faktum, at grønlænderne nu skriver deres egen historie, baseret på grønlandske kilder, der er væsentlig, men at denne historieskrivning sætter fokus på grønlændernes egen deltagelse og dermed medansvar for den historiske proces - et aspekt som fra begyndelsen har været understreget af flere af kommissionens medlemmer (Heinrich). Kommissionen har lagt stor vægt på at indsamle personlige narrativer omkring folks egen oplevelse af kolonitiden og ikke mindst overgangen til det moderne samfund efter 1953, ligesom rapporter omkring koncentrationspolitikken og fødestedskriteriet er udarbejdet. ${ }^{8}$ Man besluttede fra starten ikke at kopiere andre tilsvarende forsoningskommissioner. Den grønlandske kommission skulle således på ingen måde have karakter af en sandhedskommission, og der var ikke lagt op til, at målet var at kræve en undskyldning fra den danske stat. Den grønlandske kommission kendte udmærket til problemerne med sådanne undskyldninger, herunder formentlig blandt andet Sara Ahmeds analyse af, hvordan den australske undskyldning overfor den indfødte befolkning havde en stærk nationsbyggende effekt - for den hvide befolkning vel at mærke (Ahmed, The Cultural Politics of Emotion 101-121). Ved de afholdte folkemøder rundt omkring i Grønland er kravet om en undskyldning imidlertid til stadighed dukket op, og kommissionen sender derfor problemet videre:

Medlemmerne af Forsoningskommissionen anbefaler, at Naalakkersuisut tager initiativ til en debat om dette spørgsmål [en mulig undskyldning til borgerne for den måde de er blevet behandlet på i udviklingens navn] internt i Grønland, så hele befolkningens holdning til dette spørgsmål bliver belyst (Namminersorlutik Oqartussat 46).

Andetsteds tales der om, at den danske stat og det grønlandske selvstyre kunne give en undskyldning $i$ fællesskab, i anerkendelse af at det grønland-

8 Begge er tilgængelige på kommissionens hjemmeside: http://saammaatta.gl/da/ Forsoning/Groenlands-forsoningskommission. 
ske Landsråd i sin tid har været med til at godkende en lang række af de beslutninger, som nogle ønsker en undskyldning for (37). Rapporten bærer således præg af en betydelig uklarhed omkring, hvordan man skal forholde sig til disse spørgsmål om ansvar og skyld.

Samme uklarhed kommer til udtryk i debatten om Grønlands status som koloni eller ikke koloni. Ikke mindst hos folk, som kun har et overfladisk kendskab til Grønland, er der en automatreaktion, som tilsiger, at hvis man vil være progressiv og vise sin solidaritet med Grønland, gælder det om at erklære sig skyldig på Danmarks vegne og kræve undskyldninger på Grønlands vegne. "Exceptionalisme" er blevet det skældsord, hvormed visse historikere og debattører afviser ethvert forsøg på at se de dansk-grønlandske relationer i deres specifikke historiske kontekst. Det er imidlertid værd at lægge mærke til, at mange grønlændere selv promoverer en sådan kontekstualisering. For nuværende tages det i Grønland for givet, at Grønland var en koloni. Det er et afgørende argument i kravet om selvstændighed. At erklære sig som forhenværende koloni, eller at vælge ikke at gøre det, er således også en strategisk position. Som antropologen Michael Herzfeld har påpeget, er for eksempel Grækenland og Thailand særdeles stolte af aldrig at have været koloni, selv om mange kriterier ellers udmærket passer. Herzfeld betegner sådanne lande "kryptokoloniale". Kulturhistorikeren Ann-Sofie Gremaud har overført begrebet på Island, hvor det på samme måde er en vigtig del af den nationale fortælling, at Island aldrig underlagde sig fremmed magt. Som det fremgår af forbeholdene omkring forsoningskommissionen, er det for mange grønlændere væsentligt at understrege, at kolonialisme kommer i mange former, og at Grønland netop ikke kan sammenlignes med en hvilken som helst anden koloni. Det handler om det selvbillede, man gerne vil opbygge med henblik på udviklingen af en fremtidig selvstændig stat. Her passer billedet af de frie, stolte fangere langt bedre end billedet af underkuede, slavegjorte sorte. Ligesom det unægtelig bliver lettere at se sig selv ved roret i en moderne stat, hvis man kan identificere sig med en århundredlang proces, hvor grønlænderne har kæmpet for selvbestemmelse, modernitet og åbning af landet, end hvis man fastholder den antikoloniale diskurs om kolonimagtens brutale overgreb på et sagesløst naturfolk. 


\section{KONKLUSION}

Den grønlandske diskussion om løsrivelse fra Danmark, som forudsætter økonomisk grundlag i form af diverse storskalaprojekter og brydning af sjældne mineraler med uran som biprodukt, handler dybest set om præcis de ting, som er på spil i forhandlingen mellem Lidegaard og Kleist: at gøre grønlænderne til eget referencepunkt og at kunne træde i direkte forbindelse med verden, frem for altid at skulle gå via Danmark. Det er i dag svært for en grønlænder at indtage den position, at man ikke går ind for et selvstændigt Grønland, selv om der er stor uklarhed om hvornår (Gad 51).

Geopolitisk set er Grønland afgørende for Danmarks status. Med en serie af forskellige tiltag, som for eksempel markering af grønlandske og færøske flagdage i Danmark (fra 2016), signalerer Danmark en inklusion og anerkendelse af disse rigsdele, som imidlertid kommer noget sent og derfor får et anstrøg af det, den postkoloniale teoretiker Paul Gilroy har kaldt postkolonial melankoli. Begrebet betegner en patologisk britisk længsel efter den tid, hvor imperiet var ved sin fulde magt, med den identitet af ledende verdensmagt, som også gav identitet til den enkelte britiske medborger.

Hvis der er en snert af noget sådant i Lidegaards tekst, er det på trods af bogens erklærede hensigt. Allerede for årtier siden udskiftede Lidegaard den paternalistiske mor-barn metafor med en ægteskabsmetafor, idet også hun synes at tage det for givet, at vejen går mod skilsmisse. Dette fremgår af en tekst til en radioudsendelse fra 1999, der inkluderes som afslutning på bogen (294). Nu gælder det så blot om at få en ordentlig skilsmisse, så man måske kan blive bedre venner, end man var ægtefæller. I det perspektiv er den danske påstand om, at forsoning og afklaring er noget, som kun angår grønlænderne, næppe vejen frem. Samtalen mellem Lidegaard og Kleist demonstrerer med al ønskelig tydelighed, at der i dén grad er behov for afklaring, også på dansk side.

KIRSTEN THISTED er lektor ved Minoritetsstudier, Institut for Tværkulturelle og Regionale Studier, Københavns Universitet. Har udgivet bøger og artikler om grønlandsk fortælletradition, ny grønlandsk litteratur, film, kunst, kultur og samfundsforhold, samt om dansk- grønlandske relationer og Skandinavien set i et postkolonialt perspektiv. Leder for nuværende det internationale forskningsprojekt Denmark and the New North Atlantic, finansieret af Carlsbergfondet. 


\section{"A POISON IN THE BLOOD" \\ Affective Economies in Danish-Greenlandic Relations}

Inspired by Sara Ahmed, the article analyzes how long-established affective economies still dominate post-colonial relations between Danes and Greenlanders. Affective relationships between Greenlanders and Danes are embedded in historically inherited, asymmetric political, and financial power relations. While the political and economic conditions often are subject to analysis because data in these fields is relatively easy to access, it is much harder to access material that illuminates affective relationships. The article focuses on an email correspondence between two women, each of whom has a prominent place in the Danish-Greenlandic cultural debate. The two women know each other in advance and are both eager for the communication to succeed. It turns out not to be quite so simple. The analysis shows how the Dane, contrary to her own intentions, maintains the Greenlander in the role as the object of the Danish, evaluative and normative, gaze. The Greenlander protests against this and tries to renegotiate their positions so that the Greenlanders become subjects of their own actions and the history of Greenland. The article argues that it is not possible to understand the current political discussions, including debates on large scale projects, uranium extraction, and independence, unless these affects and their historicity are taken into account. A conversation about reconciliation must also begin here.

\section{KEYWORDS}

EN: Denmark-Greenland, post-colonial relations, affective economies, shame, reconciliation.

DA: Danmark-Grønland, postkoloniale relationer, affektive økonomier, skam, forsoning

\section{LITTERATUR}

Ahmed, Sara. The Cultural Politics of Emotion. Edinburgh: Edinburgh University Press, 2004.

Ahmed, Sara. The Promise of Happiness. Durham: Duke University Press, 2010. 
Amareya Theater. http://www.teatramareya.pl/index.php/en/performances/166-nomadka. Sidst besøgt 10. januar 2018.

Andersen, Astrid Nonbo og Kirsten Thisted. "'Whatever a Colony Is' - 1945-1953 as a Zero Hour in Danish-Greenlandic Relations". Zero Hours. Politics of Time in Global Perspectives, 1940s-1970s. Red. Hagen Schulz-Forberg. London, New York and Shanghai: Palgrave Macmillan, under udgivelse.

Braidotti, Rosi. Embodiment and Sexual Difference in Contemporary Feminist Theory. New York: Columbia University Press, 1994.

Brimnes, Niels et al. "En ny dansk kolonihistorie". Danmark og kolonierne bind 1. København: Gads Forlag, 2017. 4-7.

Fanon, Frantz. Black Skin, White Masks. Translated by Charles Lam Markmann, London: Pluto Press, 1986.

Gad, Ulrik Pram. National Identity Politics and Postcolonial Sovereignty Games. Greenland, Denmark, and the European Union. København: Museum Tusculanum Press, 2017.

Gilroy, Paul. Postcolonial Melancholia. New York: Columbia University Press, 2005.

Gremaud, Ann-Sofie. "Iceland as Centre and Periphery. Post-Colonial and Crypto-Colonial Perspectives". The Postcolonial North Atlantic. Iceland, Greenland and the Faroe Islands. Red. Lill-Ann Körber og Ebbe Volquardsen. Berliner Beiträge zur Skandinavistik, 2014. 83-104.

Heinrich, Jens. "Forsoningskommissionen og fortiden som koloni". Baggrund 28. november 2014. http://baggrund.com/forsoningskommissionen-og-fortiden-som-koloni/

Herzfeld, Michael. "The Absent Presence: Discourses of Crypto-Colonialism". The South Atlantic Quarterly 101.4 (2002): 899-926.

Kjærgaard, Thorkild. "Grønland og Hermod Lannungs private udenrigspolitik", Weekendavisen 24. februar 2017.

KNR nyheder 29. august 2013. http://knr.gl/da/nyheder/danmark-p\%C3\%A5-sidelinjen-i-forhold-til-forsoningskommission, sidst besøgt 16/10 2017.

Lidegaard, Bo. "Kolonier mig her, kolonier mig der". Politiken 29. marts 2015.

Lidegaard, Else. Med Nordlys i øjnene. Genskin fra et liv med Grønland som ballast. København: Stampenborg (i kommission hos Gyldendal), 2016.

Naalakkersuisut / Government of Greenland. Kommissorium for Forsoningskommissionen $i$ Grønland. 2014. http://naalakkersuisut.gl/ /media/Nanoq/Files/Publications/Formandens\%20Departement/Forsoningskommission/Kommissorium\%20da.pdf

Namminersorlutik Oqartussat / Grønlands Selvstyre, Formandens Departement: Vi forstår fortiden Vi tager ansvar for nutiden Vi arbejder sammen for en bedre fremtid. Betænkning udgivet af Grønlands Forsoningskommission, Nuuk, december 2017. http://saammaatta.gl/ /media/Forsoningskommission/Diverse/Endelig\%20 betænkning\%20DK.pdf

Sartre, Jean-Paul. The Anti-Semite and the Jew. Translated by George J. Becker, New York: Schoken Books Inc., 1948.

Thisted, Kirsten. "Kolonialisme og forsoning: Dansk-grønlandske relationer i en selvstyretid". Tidsskriftet Grønland, 3 (2014): 161-170. Online: https://issuu.com/greenland/ docs/tg-3-2014-isuu 


\section{KIRSTEN THISTED}

"EN GIFT I BLODET"

Wang, Niels. "Bevarelsen af Rigsfællesskabet er eksistentielt". Arktisk Nyt 12. januar 2017. http://www.arktisknyt.dk/2017/01/12/nils-wang-bevarelsen-af-rigsfaellesskabet-er-eksistentielt-arktis/

Zahavi, Dan. Self and Other. Exploring Subjectivity, Empathy, and Shame. Oxford: Oxford University Press, 2014. 
94 KULTUR \& KLASSE * $125 * 2018$ SKYLD OG SKAM I SKANDINAVIEN 